\title{
Assessment of Chemical Composition and Nutritional Value of Some Varieties of Okra Available in the Market of Daloa (Côte d'Ivoire)
}

\author{
Agnan Marie-Michel Combo ${ }^{1 *}$, Patrick Aubin Dakia ${ }^{2}$, Koffi Pierre Valery Niaba ${ }^{1}$, Nermegnon Traoré ${ }^{1}$, Grah Avit \\ Maxw ell Beugré ${ }^{1}$ \\ ${ }^{1}$ Department of Biochemis try-Microbiology, Laboratory of Agrovalorisation, University Jean Lorougnon Guédé, Daloa, Côte \\ d'Ivoire \\ ${ }^{2}$ Department of Food Science and Technology, University of Nangui Abroguoa, Abidjan, Côte d'Ivoire \\ *Corresponding author's email: comboagnan [AT] yahoo.fr
}

\begin{abstract}
Six okra varieties (F1 Yodana, Kirikou, Volta, Yeleen, Kouskoand Local) soldand consumed in Daloa (Côte d'Ivoire) were evaluated with regards to the nutritional, antioxidant and mineralcontents. The result of the study revealed that the proximate composition in dry weight basis was significantly $(P<0.05)$ varied and rang ed: dry matter 87.83-92.33\%, crude protein 13.65-22.63\%, crude fat 2.78-3.94\%, crude fiber 21.08-26.70\%, crude a sh 7.16-10.59\%, carbohydrate 39.28-54.25\%, and energy value $274.78-297.97 \mathrm{kcal} / 100 \mathrm{~g}$. Volta had the highest content in both protein and fat. Yeleen had the highest ash content, Local had the highest fiber content, while Kirikou presented the highest content in both carbohydrate and energy values. The phenoliccontent ranges from 111.42 to $156.00 \mathrm{mg} / 100 \mathrm{~g}$ while the vitamin C ranges from 25.30 to $49.60 \mathrm{mg} / 100 \mathrm{~g}$ in dry weight basis. Volta had the highest content in both phenolic and vita min $C$. The mineral contents $(\mathrm{mg} / 100 \mathrm{~g})$ in dry weight basis were also significantly $(P<0.05)$ varied. Pota ssium was the most abundant macro-element (1642.71-2519.84) followed by calcium(460.80-767.72), magnesium (345.46-432.70) and Iron (0.42-3.18) in all the varieties. Interrelationships between the parameters analysed and the different okra varie ties were investigated by principal component analysis (PCA). PCA revealed differences between the okra varieties and classified them into three groups on the basis of the measured parameters: Group 1 (F1 Yodana, Volta and Local), Group 2 (Kirikou and Kousko) and Group 3 (Yeleen). This study provided important information about the nutritional composition of okra from Daloa, which can help to increase production and consumption of these nutrient-rich veg et ables and will help reduce the nutrition-related disorders in Africa.
\end{abstract}

Keywords - Okra, proximate composition, nutrients constituents, Côte d'Ivoire

\section{INTRODUCTION}

Vegetables havelong been part of diets in communities worldwide and contributesub stantially to food security [1]. Vegetables are valuable sources of nutrients, with some having important medicinal properties [2, 3, 4].

Okra (Abelmoschus esculentus L.) is one of the oldestcultivated crops and presently grown in man y countries and is widely distributed fromAfrica to Asia, southern Europe and America [5]. It is one of the most widely known and utilized species of the family Malvaceae. The nutritional potential of okra (mineral elements, protein, fiber, antioxidants and vitamins) has been reported by many researchers $[6,7,8]$. In addition, this plant has a wide range of medicinal values and has been used to treat many diseases. Some authors reported that okra owns the antioxidation and anti-diabetes activities, cures ulcers and relief from hemorrhoids, and reduces blood lipid $[9,10,11]$.

In West Africa, okra is in second place in vegetable production behind tomatoes [12]. It is mainly cultivated for its immature fruits which are eaten after cooking. The plant is also cultivated because the leaves can be consumed and the $s$ te $\mathrm{m}$ used for fiber and rope. In Côte d'Ivoire, okra occupies an important placein the diet. With $5.5 \mathrm{~kg}$ of fresh fruit per inhabitant 
/ year, okra comes first ahead of the eggplant (3.7 kg / inhabitant) and the tomato (1.4 kg / inhabitant), among the vegetables of great consumption in Côte d'Ivoire [13]. The fruits are used in both fresh and dried forms. It represents $24 \%$ of the vegetables consumed fresh and $41 \%$ of vegetables consumed dried [14]. Des pite the exceptional characteris tic s of o kra, it remains a marginalized, minor crop and an es sentially feminine activity. Several varieties exist on the Ivorian market with different forms and different production cycles. But little is known about their nutritional quality. Assessing the nutritional importance of these varieties can lead to a better understanding of the value of these plants. The refore, this work aims to evaluate the nutritional characteristics of the different okra varieties sold and consumed in Daloa (Côte d'Ivoire) to in crease the uptake/promotion of these vegetables.

\section{MATERIALS AND METHODS}

\subsection{Materials}

The biological material used in this study consisted of six varieties of okra, namely F1 Yodana, Kirikou, Volta, Yeleen, Kousko and Local (Fig. 1). The samples of okra were collected in the region of Daloa (Côte d'Ivoire). They were fres $h$ and without infections or wounds.
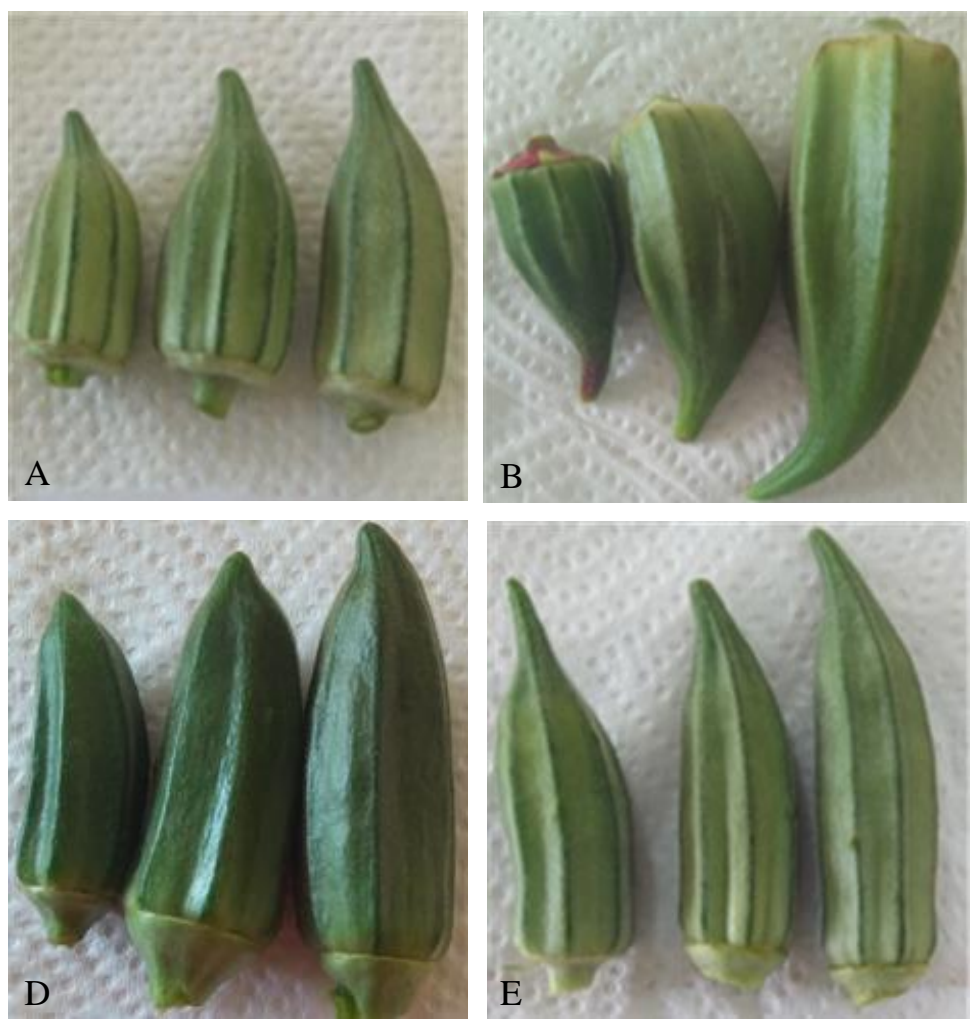
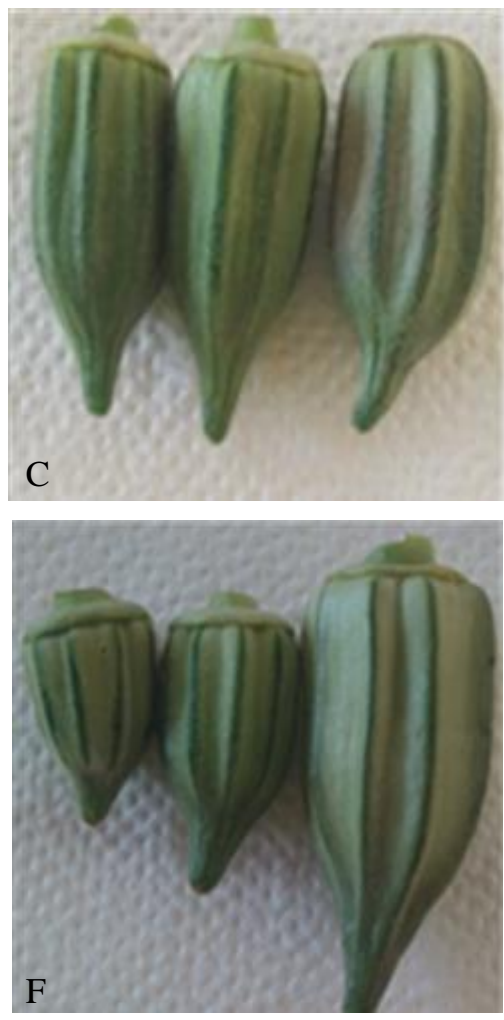

Figure 1: Varieties of Okra studied: A) F1 Yodana; B)Local; C) Kirikou; D) Kousko;E) Volta; F) Yeleen

\subsection{Sample Preparation}

The okra fruits were sorted, washed, stumps trimmed off (with stainless steel knife) and then consumable parts we re cut longitudinally into portions of equal size. The samples were oven-dried at $70^{\circ} \mathrm{C}$ for $24 \mathrm{~h}$. The dried material obtained was ground to a fine powder and finally packed into airtight polyethylene plastic bottles and stored in the desiccator until required for analysis. The dry samples were analysed for proximate composition, minerals ( $\mathrm{Ca}, \mathrm{Mg}$, Fe and $\mathrm{K}$ ), vit amin $\mathrm{C}$ and to tal phenolic content. Determinations were carried out by duplicate. The res ults are expressed as g per one hundred (100) $\mathrm{g}$ of dry weight $(\mathrm{g} / 100 \mathrm{~g}$ DW $)$.

\subsection{Determination of Proximate Composition}


Okra samples were analyzed for their $\mathrm{pH}$ and dry matter [15]. One hundred (100) $\mathrm{mL}$ of distilled water was homogenized with $10 \mathrm{~g}$ of sample, and the $\mathrm{pH}$ was measured with a combined glass electrode $\mathrm{pH}$-meter (Hanna Instru ments, Ro mania). Dry matter was determined by hot oven (Memmert, Schwabach, Germany) drying at $105^{\circ} \mathrm{C}$ for $24 \mathrm{~h}$ to constant weight. Crude fat determination was carried out by Soxhlet extraction of a $10 \mathrm{~g}$ sample, with hexane as solvent [16]. Ash content was determined using the muffle furnace at $550{ }^{\circ} \mathrm{C}$ during $24 \mathrm{~h}$ according to the AOAC method [17]. Crude protein was determined by using Kjeldahl method in which percent nitrogen $(\mathrm{N})$ was multiplied by 6.25 to convert the percent $\mathrm{N}$ in to percent crude protein [18]. Crude fiber was determined by digestion method [19]. Two (2) g of sample was accurately weighed and transferred into beaker containing $50 \mathrm{~mL}$ of $\mathrm{H}_{2} \mathrm{SO}_{4}(0.25 \mathrm{~N})$. After boiling for 30 min under reflux refrig erant, $50 \mathrm{~mL}$ of $\mathrm{NaOH}(0.31 \mathrm{~N})$ was added and boiled. After $30 \mathrm{~min}$, the solution was filtered. Residues were washed with hot water and transferred to crucible. Crucible containing residue was dried at $105^{\circ} \mathrm{C}$ for $8 \mathrm{~h}$ to a constant weight. The crucible was then cooled in a desiccator and weighed. The residues were placed in muffle furnace at $550^{\circ} \mathrm{C}$ for $3 \mathrm{~h}$ and then the sample was cooled in a desiccator and weighed. Results were expressed as shown in equation 1:

$$
\text { Crude fiber }(\%)=\frac{\text { Weight of residue }- \text { Weight of ash }}{\text { Weight of sample } \times \text { Dry weight }} \times 100
$$

Total carbohydrate content was calculated adding the total values of crudeprotein, crude fat, crude fiber and to tal as $h$ contents of the sample and subtracting it from 100\% according to the equation 2 [20].

$$
\text { Total carbohydrate }(\%)=100-(\% \text { protein }+\% \text { ash }+\% \text { fat }+\% \text { crude fiber })
$$

The energy value was calculated from the total carbohydrate content, crude protein and crude fat us ing the conversion factors for energy (Atwater factors such as $4 \mathrm{kcal}$ per $1 \mathrm{~g}$ of carbohydrate, $9 \mathrm{kcal}$ per $1 \mathrm{~g}$ lipid and $4 \mathrm{kcal}$ per $1 \mathrm{~g}$ of protein ) [21].

\subsection{Determination of Mineral Content}

The mineral content ( $\mathrm{Ca}, \mathrm{Mg}, \mathrm{K}$ and $\mathrm{Fe}$ ) was determined using an atomic absorption spectrophotometer (Thermo Scientific iCE 3000 Series ) according to the procedure reported by Kouassi et al. [22]. Ashing of the samples was followed by digestion and absorption. The as hed sample $(0.25 \mathrm{~g})$ was mixed with $30 \mathrm{~mL}$ of $1 \%$ nitric acid. The extract obtain ed was filtered using whatman filter paper, then collected in a $100 \mathrm{~mL}$ flask and adjus ted with dis tilled water. The supern at ant was puted into clean vials for mineral determination. The absorbance was read on atomic absorption spectrophotometer at different wavelength for each mineral element (Ca-422.7 nm, Fe-248.3 nm, Mg-285.2 nm, and K-766.5 nm). All results were expressed on per $100 \mathrm{~g}$ of dry weight basis.

\subsection{Determination of Antioxidants}

The amount of total phenolic content in the okra was determined using theFolin-Ciocalteu re agent and gallic acid as standard [23]. Methanolic extracts of okra $(1 \mathrm{~mL})$ were transferred into different test tubes, and then mixed with $1 \mathrm{~mL}$ of Folin-Ciocalteu reagent. After $3 \mathrm{~min}$ for allowing the reaction to take place, $1 \mathrm{~mL}$ of $20 \%$ sodiumcarbonate $\left(\mathrm{Na}_{2} \mathrm{CO}_{3}\right)$ was added. The test tubes were placed in the dark for $30 \mathrm{~min}$ at ambient temperature, and the absorption was measured at $725 \mathrm{~nm}$ using spectrophotometer(DR 3900) ag ainst a blank, which contained methanol in place of sample. Gallic acid was us ed as calibration standard, and the total phenolic content was expressed as gallic acid equivalent in $\mathrm{mg} / 100 \mathrm{~g}$ dry weight (mg GAE/100 g DW).

The amount of as corbic acid (Vitamin C) was determined according to the 2, 6-dichlorophenol-indophenols dye method of Pongracz et al. [24]. Ten (10) g of each sample (powdered okra) was mixed with $40 \mathrm{~mL}$ of $2 \%$ metaphosphoric acid at room temperature. The mixture obtained was centrifuged at $3000 \mathrm{rpm}$ for $20 \mathrm{~min}$. The supernatant was introduced in to a 50 $\mathrm{mL}\left(\mathrm{V}_{1}\right)$ flask and adjusted with distilled water. Test sample $\left(10 \mathrm{~mL}, \mathrm{~V}_{2}\right)$ of the diluted sample was titrated with 2,6dichloroindophenol (2,6-DCPIP, $0.5 \mathrm{~g} / \mathrm{L})$ until it turns pale pink. Percentage of vitamin C content was calculated by using the equation 3:

$$
\operatorname{Vitamin} C(\%)=\frac{(C \times V) \times V_{1}}{W \times V_{2} \times D W} \times 100
$$

Where, $\mathrm{V}=$ Volume $(\mathrm{mL})$ of 2,6-DCPIP required to titrate sample, $\mathrm{V}_{2}=$ Volume $(\mathrm{mL})$ of test sample, $\mathrm{C}=$ Concentration $(\mathrm{g} / \mathrm{L})$ of 2,6-DCPIP, $\mathrm{V}_{1}=$ Volume $(\mathrm{mL})$ of diluted sample, $\mathrm{W}=$ weight of s ample $(\mathrm{g}), \mathrm{DW}=$ dry weight

\subsection{Statistical Analysis}


The statistical processing of the data consisted of an analysis of variance (ANOVA) with a clas sification criterion u sing the SPSS software (SPSS 20.0 for Windows, SPSS Inc.). Means were compared by the Duncan test at the 5\% sig nific ance level. A principal component analy sis (PCA) was also carried out using R software (version 3.5.0) in order to structure the variability between okra and nutritive content.

\section{RESULTS AND DISCUSSION}

\subsection{Proximate Composition}

The proximate and nutrient analyses of okra play a crucial role in as sessing its nutritional signific ance. The proximate composition for the mean dry weight, $\mathrm{pH}$, ash, crude fat, crude protein, crude fiber, total carbohydrate an d en ergy values found in the present work are shown in Table 1. The result shows that the $\mathrm{pH}$ values of the different okra varietie s were not significantly different $(\mathrm{P}<0.05)$. It varied respectively from 5.80 to 6.06. These findings are consistent with those of Nair and Fahs a [25] who reported $\mathrm{pH}$ values with a range of 5.2-6.4 for five varieties of okra.

Table 1: Proximate Composition of Okra Varieties (on dry weight basis).

\begin{tabular}{|c|c|c|c|c|c|c|}
\hline Composition (\%) & $\begin{array}{c}\text { F1 } \\
\text { Yodana }\end{array}$ & Local & Kirikou & Kousko & Volta & Yeleen \\
\hline $\mathrm{pH}$ & $\begin{array}{c}5.84^{\mathrm{a}} \pm \\
0.01\end{array}$ & $\begin{array}{c}5.80^{\mathrm{a}} \pm \\
0.01\end{array}$ & $\begin{array}{c}5.87^{\mathrm{a}} \pm \\
0.02\end{array}$ & $\begin{array}{c}5.82^{\mathrm{a}} \pm \\
0.09\end{array}$ & $\begin{array}{c}6.06^{\mathrm{a}} \pm \\
0.99\end{array}$ & $\begin{array}{c}5.96^{\mathrm{a}} \pm \\
0.40\end{array}$ \\
\hline DM & $\begin{array}{c}91.94^{\mathrm{d}} \pm \\
0.15\end{array}$ & $\begin{array}{c}87.83^{\mathrm{a}} \pm \\
0.20\end{array}$ & $\begin{array}{c}90.39^{\mathrm{c}} \pm \\
0.39\end{array}$ & $\begin{array}{c}88.61^{\mathrm{b}} \pm \\
0.31\end{array}$ & $\begin{array}{c}90.00^{c} \pm \\
0.02\end{array}$ & $\begin{array}{c}92.33^{\mathrm{d}} \pm \\
0.02\end{array}$ \\
\hline Crude protein & $\begin{array}{c}21.41^{\mathrm{cd}} \pm \\
0.70\end{array}$ & $\begin{array}{c}21.92^{\text {de }} \pm \\
0.28\end{array}$ & $\begin{array}{c}13.65^{\mathrm{a}} \pm \\
0.59\end{array}$ & $\begin{array}{c}20.48^{\mathrm{c}} \pm \\
0.28\end{array}$ & $\begin{array}{c}22.63^{\mathrm{e}} \pm \\
0.34\end{array}$ & $\begin{array}{c}14.77^{\mathrm{b}} \pm \\
0.34\end{array}$ \\
\hline Crude fat & $\begin{array}{c}2.98^{\mathrm{a}} \pm \\
0.08\end{array}$ & $\begin{array}{c}2.78^{\mathrm{a}} \pm \\
0.09\end{array}$ & $\begin{array}{c}2.92^{\mathrm{a}} \pm \\
0.22\end{array}$ & $\begin{array}{c}3.30^{\mathrm{a}} \pm \\
0.04\end{array}$ & $\begin{array}{c}3.94^{\mathrm{a}} \pm \\
0.08\end{array}$ & $\begin{array}{c}3.19^{\mathrm{a}} \pm \\
0.69\end{array}$ \\
\hline Ash & $\begin{array}{c}7.84^{\mathrm{b}} \pm \\
0.29\end{array}$ & $\begin{array}{c}8.09^{\mathrm{bc}} \pm \\
0.04\end{array}$ & $\begin{array}{c}8.08^{\mathrm{bc}} \pm \\
0.07\end{array}$ & $\begin{array}{c}7.16^{\mathrm{a}} \pm \\
0.03\end{array}$ & $\begin{array}{c}8.44^{\mathrm{c}} \pm \\
0.01\end{array}$ & $\begin{array}{c}10.59^{\mathrm{d}} \pm \\
0.27\end{array}$ \\
\hline Crude fiber & $\begin{array}{c}23.48^{\mathrm{bc}} \pm \\
0.61\end{array}$ & $\begin{array}{c}26.70^{\mathrm{e}} \pm \\
0.37\end{array}$ & $\begin{array}{c}21.08^{\mathrm{a}} \pm \\
1.26\end{array}$ & $\begin{array}{c}24.09^{\mathrm{cd}} \pm \\
0.64\end{array}$ & $\begin{array}{c}25.71^{\text {de }} \\
0.38\end{array}$ & $\begin{array}{c}22.03^{\mathrm{ab}} \pm \\
0.75\end{array}$ \\
\hline Totalcarbohy. & $\begin{array}{c}44.29^{\mathrm{b}} \pm \\
1.11\end{array}$ & $\begin{array}{c}40.50^{\mathrm{a}} \pm \\
0.22\end{array}$ & $\begin{array}{c}54.25^{\mathrm{d}} \pm \\
1.56\end{array}$ & $\begin{array}{c}44.96^{\mathrm{b}} \pm \\
0.92\end{array}$ & $\begin{array}{c}39.24^{\mathrm{a}} \pm \\
0.66\end{array}$ & $\begin{array}{c}49.41^{\mathrm{c}} \pm \\
1.50\end{array}$ \\
\hline $\mathrm{EV}(\mathrm{kcal} / 100 \mathrm{~g})$ & $\begin{array}{c}289.61^{\mathrm{bc}} \pm \\
0.91\end{array}$ & $\begin{array}{c}274.78^{\mathrm{a}} \\
\pm 1.18\end{array}$ & $\begin{array}{c}297.97^{\mathrm{d}} \pm \\
5.89\end{array}$ & $\begin{array}{c}291.53^{\mathrm{cd}} \pm \\
2.24\end{array}$ & $\begin{array}{l}283.08^{\mathrm{b}} \\
\pm 1.97\end{array}$ & $\begin{array}{c}285.47^{\mathrm{bc}} \\
\pm 1.55\end{array}$ \\
\hline
\end{tabular}

Values are averages \pm standard deviation of replicate determinations $(n=2)$. Means not followed by the same supers cript letters in the same row are significantly different $(\mathrm{P}<0.05)$. $\mathrm{DM}=$ Dry matter, Total carbohy $=$ Total carbohydrate, $\mathrm{EV}=$ Energy value.

The dry matter content of a sample corres ponds to its mass after completeevaporation of free water. These rates range from 87.83 to $92.33 \%$ for the six varieties of okra. The results show significant differences $(\mathrm{P}<0.05)$ between dry matter content of the sample. Indeed, these low water contents reflect the high solids content of the samples. This facilitates their preservation. Yeleen variety was observed to have the highest content while Localvariety had the least. These valu es are in agreement with high dry matter content in okra pods at $86.67-90.31 \%$ as previously reported [8].

Proteins play a particularly important role in human nutrition. The amino acid contents, proportions, and their digestibility by humans characterize a protein's biological value [26]. The protein content of the studied okra varieties ran ged betwe en $13.65-22.63 \%$ on dry weight basis. These values were in the same range of the protein values $(10.25-26.12 \%)$ rep orted for okra varieties [8]. Kirikou variety had the least protein content while Volta variety had the highest; this could be due to genetic factor. Okra can be considered as a high protein vegetable. Thus, a diet containing these varieties of ok ra would be beneficial to health, knowing the important role played by proteins in the body.

The fat content in the studied okra varieties is reported in Table 1. It varied from 2.78-3.94\% on dry weight ba sis . Volt a variety had the highest content of fat which was not significantly different fromall other varieties. The fat con tent in the se 
okra varieties is low in comparis on with the range of fat (4.34-4.52\%) reported by Samiet al. [27]. This difference may be due to the genetic factor of the varieties.

The ash content is the total quantity of minerals present in the sample. The ash content in the okra varietie s varie $\mathrm{d}$ from 7.16-10.59\% on dry weight basis. These results were approximate to those reported by other researchers [6]. Thes e res ults indicate that these okra varieties would provide essential valuable and useful minerals needed for body development.

Interest in fiber evaluation has increased due to the potential role of dietary fiber in human nutrition [28]. Diet ary fiber helps to stabilize blood sugar by regulating the rate at which sugar is absorbed from the intestinal tract [29]. Fiber also promotes the growth and protects the beneficial intes tinal flora. Moreover, high intake of fib er red uces the ris k of colon cancer [30]. Crude fiber in all the samples differed significantly and ranged from 21.08 to $26.70 \%$ on dry weight basis. Adetuyi et al. [6] reported that the fiber content of Okra pod ranges from 10.15 to $11.63 \mathrm{~g} / 100 \mathrm{~g}$ which is lower than the crude fiber obtained in the present study. The crude fiber contents were however, within the range of the crudefiberc on tent (11.97-29.93\%) of okra reported previously [8]. The high value of fiber reported for okra fruit can improve its dig estibility and abs orption processes in large intes tine, helping to stimulate peristalsis, thereby preventing constipation [31].

Carbohydrate is essential for energy production in the human body [32]. The total carbohydrate contents of the six varieties of okra used in this study are shown in Table 1. Totalcarbohydrates ranged from 39.28 to $54.25 \%$ on dry weight bas is. Similar results have also been found [8]. The high levels were observed in Kirikou, Yeleen, Kous ko and F1 Yod an a varieties; indicating that these varieties contain more mucilage and this implies that these okra can serve as a good source of carbohydrate or poly saccharide. Researchers [33] have shown that okra polysaccharides are particularly effective at inhibiting the adhesion of Helicobacter pylori bacteria on gastric tis sues, preventing the spread of thesebacteria. Therefore, eating more okra can keep the stomach clean and create an environment that prevents destructive cultures fromflourishing.

The results of the energy values showed significant differences $(\mathrm{P}<0.05)$ between varieties. The average energy valu es content range from $274.78 \mathrm{kcal} / 100 \mathrm{~g}$ to $297.97 \mathrm{kcal} / 100 \mathrm{~g}$. Kirikou variety had the highest energy value while Local varie ty had the least. These energy values indicate that these okra varieties can serve as a good source of energy for the body.

These chemical composition values confirmed that okra is an excellent food source, justifying its direct use in hu man nutrition.

\subsection{Antioxidant Contents}

Table 2 shows the total phenolic and vitamin C contents of the six studied okra varieties. The result of the total phe nolic content of the present investigation was expres sed as mg gallic acid equivalent (GAE) per $100 \mathrm{~g}$ s ample on dry weight basis . Significant difference was found between the varieties $(\mathrm{P}<0.05)$. Phenolic compounds were considered as a major gro up of compounds that contributed to the antioxidant activity of okra. It varied between $111.42 \mathrm{mg}$ GAE/100 $\mathrm{g}$ and $156.00 \mathrm{mg}$ GAE/100 g. The order of total phenolic contents was as follow: Volta $>$ F1 Yodana $>$ Local $>$ Yeleen $>$ Kou s ko $>$ Kirikou . The total phenolic contents of the varieties of okra were comparable with those of common vegetables such as celery lea ves (113.0 mg GAE/100 g), red pepper (173.20 mg GAE/100 g), salad (116.20 mg GAE/100 g), lettuce (124.50 mg GAE/100 g), broccoli (101.70 mg GAE/100 g), red onion (154.10 mg GAE/100 g) [34]. Plants rich in phenolics are being used in the food industry because they retard oxidative degradation of lipids and improve the quality and nutritional value of food [35].

Table 2: Antioxidant Contents of Okra Varieties

\begin{tabular}{lcc}
\hline Varieties & $\begin{array}{c}\text { Total phenolics } \\
(\mathrm{mg} \mathrm{GAE} / 100 \mathrm{~g} \mathrm{DW})\end{array}$ & $\begin{array}{c}\text { Vitamin C } \\
(\mathrm{mg} / 100 \mathrm{~g} \mathrm{DW})\end{array}$ \\
\hline F1 Yodana & $146.20^{\mathrm{c}} \pm 4.05$ & $47.00^{\mathrm{d}} \pm 0.90$ \\
Local & $126.54^{\mathrm{b}} \pm 5.03$ & $34.73^{\mathrm{b}} \pm 1.30$ \\
Kirikou & $111.42^{\mathrm{a}} \pm 6.43$ & $40.87^{\mathrm{c}} \pm 0.40$ \\
Kousko & $116.73^{\mathrm{ab}} \pm 2.32$ & $42.11^{\mathrm{c}} \pm 0.15$ \\
Volta & $156.01^{\mathrm{d}} \pm 2.34$ & $49.60^{\mathrm{d}} \pm 1.76$ \\
Yeleen & $123.55^{\mathrm{b}} \pm 1.54$ & $25.30^{\mathrm{a}} \pm 2.32$
\end{tabular}

Values are averages \pm standard deviation of replicate determinations $(n=2)$. Means not followed by the same supers cript letters in the same column are significantly different $(\mathrm{P}<0.05)$. GAE: Gallic acid equivalent, DW: Dry weight. 
The vitamin C or ascorbic acid is a water soluble vitamin and possesses a good antioxidant property [36]. The results showed that there were significantly differences $(\mathrm{P}<0.05)$ between the okra varieties. The vitamin $\mathrm{C}$ content of the ses okra varieties ranged from $25.30 \mathrm{mg} / 100 \mathrm{~g}$ to $49.60 \mathrm{mg} / 100 \mathrm{~g}$ on dry weight basis (Table 2). These values were lower to those reported for fresh okra (71.30 mg/100 g DW) [37]. The reduction of the vitamin Ccontent in okra is the result of the drying processes which is known to accelerate oxidation of as corbic acid [38].

\subsection{Mineral Composition}

The minerals present in vegetables are essential for the functioning of the organis $m$ and its development [39]. Four different minerals were analyzed for theirconcentration in dry weight basis (mg/100 g DW). According to the res ults of minerals quantification, the major element found were potassium(K: 1642.71-2519.84 mg/100 g) followed by calciu m (Ca: 460.80-767.72 mg/100 g), magnesium (Mg: 345.46-432.70 mg/100 g) and iron (Fe: 0.42-3.18 mg/100 g) in all varieties (Table 3). Researchers [40] have pointed out that in okra fruits, the mineral contents were in the order of P $>\mathrm{K}>\mathrm{Ca}>\mathrm{Mg}>$ $\mathrm{Na}>\mathrm{Fe}$, which als o signifies their relative functional importance in growth and metabolis $\mathrm{m}$. Table 3 also revealed that there was a significant $(\mathrm{P}<0.05)$ difference in the mineral compositions of okra varieties.

Table 3: Mineral Contents of Okra Varieties (mg/100 g on dry weight basis)

\begin{tabular}{lcccc}
\hline Varieties & $\mathrm{K}$ & $\mathrm{Ca}$ & $\mathrm{Mg}$ & $\mathrm{Fe}$ \\
\hline F1 Yodana & $2519.84^{\mathrm{e}} \pm 33.16$ & $703.21^{\mathrm{bc}} \pm 83.90$ & $423.52^{\mathrm{e}} \pm 0.81$ & $1.67^{\mathrm{b}} \pm 0.08$ \\
Local & $2326.16^{\mathrm{c}} \pm 31.79$ & $732.76^{\mathrm{bc}} \pm 6.88$ & $400.89^{\mathrm{d}} \pm 3.21$ & $3.18^{\mathrm{e}} \pm 0.14$ \\
Kirikou & $1903.53^{\mathrm{b}} \pm 4.19$ & $574.68^{\mathrm{ab}} \pm 30.57$ & $345.46^{\mathrm{a}} \pm 4.80$ & $2.03^{\mathrm{c}} \pm 0.18$ \\
Kousko & $1642.71^{\mathrm{a}} \pm 18.03$ & $505.73^{\mathrm{a}} \pm 14.29$ & $359.40^{\mathrm{c}} \pm 1.10$ & $0.42^{\mathrm{a}} \pm 0.12$ \\
Volta & $2462.55^{\mathrm{d}} \pm 5.33$ & $460.80^{\mathrm{a}} \pm 11.71$ & $352.38^{\mathrm{b}} \pm 0.96$ & $2.64^{\mathrm{d}} \pm 0.15$ \\
Yeleen & $2414.30^{\mathrm{d}} \pm 13.87$ & $767.72^{\mathrm{c}} \pm 157.33$ & $432.70^{\mathrm{f}} \pm 0.91$ & $2.53^{\mathrm{d}} \pm 0.16$ \\
\hline
\end{tabular}

Values are averages \pm standard deviation of replicate determinations $(n=2)$. Means not followed by the same superscript letters in the same column are significantly different $(\mathrm{P}<0.05)$.

Result of potassiumcontent appeared to be far higher than the potassiumcontents of okra varieties, vary ing betwe en $122.59 \mathrm{mg} / 100 \mathrm{~g}$ to $318.20 \mathrm{mg} / 100 \mathrm{~g}$ [8]. High amount of potassium in the body was reported to increase iron utilization [41] and beneficial to people taking diuretics to control hypertension and suffer fromexces sive excretion of potassiu mthrough the body fluid [42].

The content of calciumin the studied okra varieties was comparable to the values of calcium(515.22-564.84 $\mathrm{mg} / 100 \mathrm{~g}$ ) previou sly reported [43]. A similar result concerning magnesiumcontent was also found [43]. Calcium and magnesium play a significant role in photosynthesis, carbohydrate metabolismand nucleic acids. Magnesiumis essentialmineral for en zy me activity, like calciumand chloride; magnesiumalso plays a role in regulating the acid-alkaline balance in the body. High magnesiumlevels in drinking water have been linked to resis tance to heart dis ease [44].

The iron content found in the present study was lower than the value (14.98 mg/100 g and $17.40 \mathrm{mg} / 100 \mathrm{~g})$ reported [39] for two varieties of okra, but higher than theiron contents $(0.87-0.96 \mathrm{mg} / 100 \mathrm{~g})$ of the local okra varieties fromNig e ria [6]. The main role of iron is the transport of oxygen to the tissues which is the active constituent of hemoglobin in red blood ce lls. Iron also enhances the body's immune system thus reducing infections and fostering proper functioning of other organs of the body [45].

\subsection{Results of the Principal Component Analysis.}

In the principal componentanalysis (PCA) the F1 axis (Factor 1) alone represents $39.29 \%$ of the totalinertia while the F2 axis (Factor 2) has $34.18 \%$ of the inertia (Figure 2a). The F1 and F2 axes therefore explained $73.47 \%$ of the total information. The level of connection between the parameters, represented by the geometric angles between the arrows, explain s their correlation. Observation of the correlation circle (Figure 2a) showed that most of the parameters studied were well represented. Apart fromlipids parameter, the other parameters are close to the circle. The point cloud of the sixvarieties of okra from the PCA revealed the presence of three groups according to their similarity criteria (Figure $2 b$ ).

The first group consisted of three okra varieties i.e. F1 Yodana, Local and Volta located in the center part of the PCA plot. The second group composed by Kirikou and Kousko was observable in the lower part. The third group composed by Yeleen 
alone, occupied an isolated location at the upper part of the figure. The similarity of the three varieties of group 1 is due to their high content of proteins, fibers, phenolics and potassium. The similarity of the 2 varieties of group 2 is due to their hig $h$ energy values and their low potassium and iron contents. The variety of group 3 is distinguished by its high content in as $h$, calcium and magnesiumbut als o its low vitamin C content.

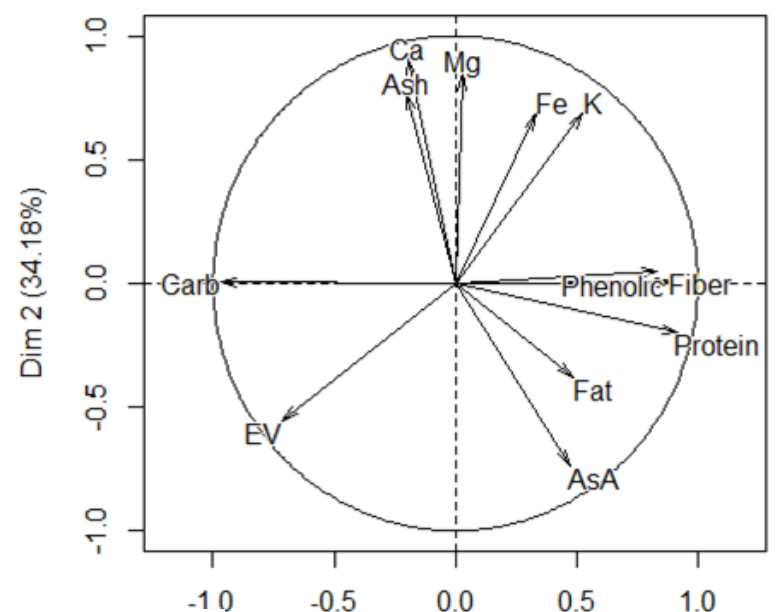

a)

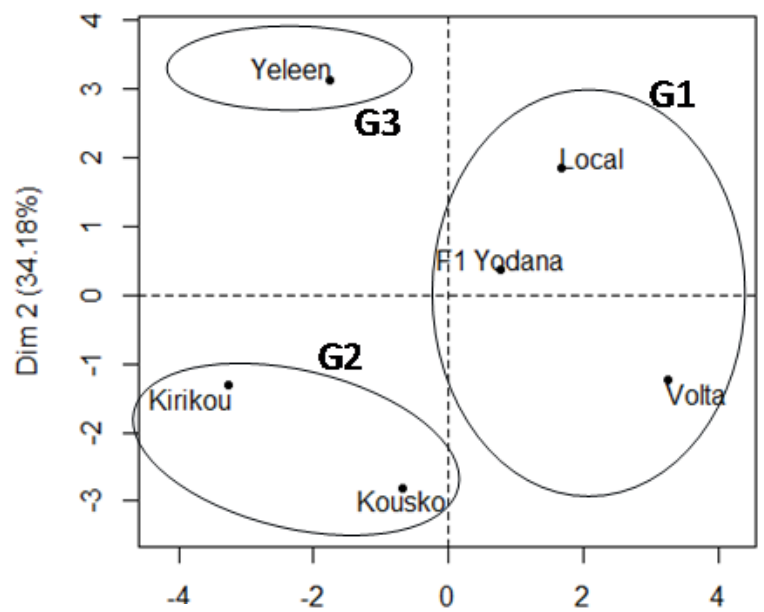

b)

$\operatorname{Dim} 1(39.29 \%)$

Figure 2: Principal Component A nalysis: a) Correlation circle ( $\mathrm{Carb}=$ carbohydrate, $\mathrm{AsA}=$ ascorbic acid, $\mathrm{EV}=$ energy value); b) Clustering of okra varieties on the factorial plane $(\mathrm{G} 1=\operatorname{group} 1, \mathrm{G} 2=\operatorname{group} 2, \mathrm{G} 3=\operatorname{group} 3)$

The result of the hierarchical cluster analy sis (HCA) is shown as a dendrogram(Figure 3 ) in which three well defined clusters (group 1, group 2 and group 3) were visible. Group 1 was composed of F1 Yodana, Volta and Local; Group 2 comprised Kirikou and Kousko and group 3 contained Yeleen alone. This is in agreement with the res ults of the PCA.

Figure 3: Dendrogram

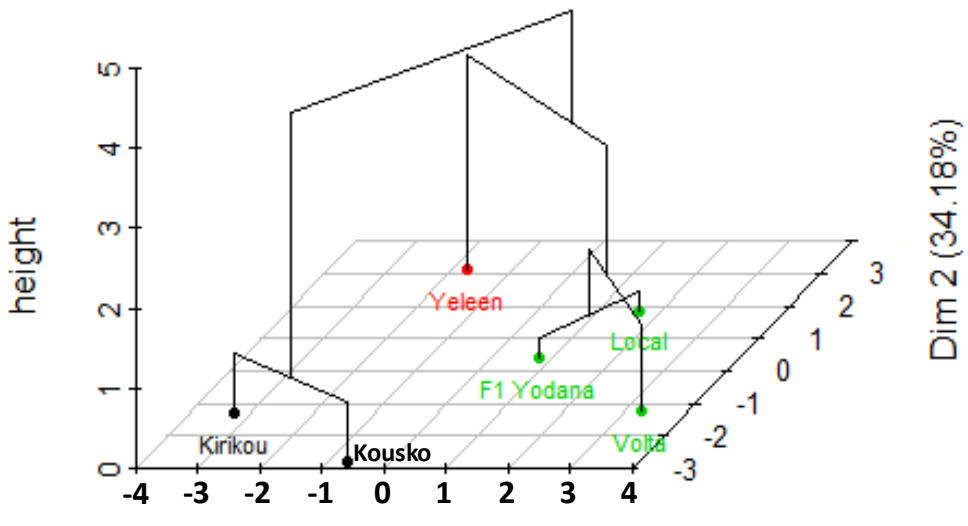

\section{$\operatorname{Dim} 1$ (39.29\%)}

of Okra Varieties. of HierarchicalClusters 


\section{CONCLUSION}

This study provides information on proximate composition and mineral and antioxidant contents of six varieties of okra growing in Daloa (Côte d'Ivoire). The analyses showed that these varieties of okra can provide nutrient-rich products considering protein, fiber, as h, magnesium, calcium, potassiumand iron as quality indices, with s light differences in the quantities of proximate and minerals contents. The results on total phenolics and vitamin $\mathrm{C}$ proved that appreciable antioxidants were present in the fruits of the studied okra varieties. Therefore, promoting the consumption of such nutritio us vegetables will be beneficial to human health by providing thenecessary macro-elements and energy to the body. The results obtained showed als o that okra constitutes an important source of antioxidants that could boost immune body system.

\section{REFERENCES}

[1] Yiridoe, E.K., Anchirinah, V.M., "Garden production systems and food security in Ghana: characteristics of traditional knowledge and management systems", Renewable Agriculture and Food Sy stems, Vol. 20, no. 3, pp. 168180, 2005.

[2] Nesamvuni, C., Steyn, N.P., Potgieter, M.J., "Nutritional value of wild, leafy plants consumed by the Vhavend a", South African Journal of Science, vol. 97, no. 1-2, pp. 51-54, 2001.

[3] Hilou, A., Nacoulma, O. G., Guiguemde, T. R., "In vivo antimalarial activities of extract fromAmaranthus spinosus L., and Boerhaavia erecta L", Journal of Ethnopharmacology, Vol. 103, no. 2, pp. 236-240, 2006.

[4] Yang, R.Y. Keding, G.B., Nutritional contributions of important African indigenous vegetables. In C. M. Shackleton, M. W. Pasquini and A. W. Drescher, eds. African indigenous vegetables in urban agriculture, Earthscan, London, 2009.

[5] Saifullah, M., Rabbani, M.G., "Evaluation and characterization of okra (Abelmoschus esculentus L. Moench.) genotypes", SAARC Journal of Agriculture, Vol. 7, no. 1, pp. 92-99, 2009.

[6] Adetuyi F.O., Osagie A.U., Adekunle A.T., "Nutrient, antinutrient, mineral and zinc bioavailability of okra Abelmoschus esculentus (L) Moench Variety", America Journal of Food Nutrition, vol. 1, no. 2, pp. 49-54, 2011.

[7] Ray, T.J., Ricky, J.P., Mobarak, B., Pacalna, O., Sotero, O., Malayao J.R., "Exploratory investigation on the hypoglycemic effect of Abelmoschus esculentus in mice", International Journal of Scientific and Technology Research, vol. 2, no. 11, pp. 249-253, 2013.

[8] Gemede, H F., Haki, G D., Beyene, F., Woldegiorgis, A Z., Rakshit, S K., "Proximate, mineral, and antinutrient compositions of indigenous Okra (Abelmoschus esculentus) pod accessions: implications for mineral bioavailability", Food Science \& Nutrition, vol. 4, no. 2, pp. 223-233, 2016.

[9] Arapitsas, P., "Identification and quantification of polyphenolic compounds from okra seed s and skins", Food Chemistry, vol. 110, no. 4, pp. 1041-1045, 2008.

[10] Gemede, H.F., Ratta, N., Haki, G.D., Woldegiorgis, A.Z., Beyene, F., "Nutritional quality and health benefits of Okra (Abelmoschus esculentus): A review”, International Journal of Nutrition and Food Sciences, vol. 4, no. 2, p p. 208-215, 2015.

[11] Dubey, P., Mishra, S., “A review on:Diabetes and okra (Abelmoschus esculentus)”, Journal of Me dicinal Plants Studies, vol. 5, no. 3, pp. 23-26, 2017.

[12] Yézoumi, A., Atsou, A., Komi, O., Akossiwa, M.Q. "Micro-propagation in vitro de deux espèces de gombo: Abelmoshus esculentus et Abelmoshus cannabinus", Cahiers Agricultures, vol. 5, no.2, pp. 109-111, 1996.

[13] DSDI., Annuaire des Statis tiques Agricoles. Les Séries Stat'Agri. Direction des Statistiques et de la Documentation (DSDI). Minis tère d'Etat, Minis tère de l'Agriculture, Abidjan, RCI, 2005.

[14] Siemonsma, J.S., "Culture of okra Legume, a tropical fruit with special reference to the Ivory Coast (Abelmoschus spp.)", Thesis, University of W ageningen (Netherlands), 1982.

[15] AOAC. Official methods of analysis, VA: As sociation of Official Analytical Chemists, Arlington, Washington D.C, 1995.

[16] Razon, L.F., Bacani, R.L., Evangelista, R.L., Knothe G., "Fatty acid profile of kenaf seed oil", Journal of the American Oil Chemists Society, vol. 90, no.6, pp. 835-840, 2013.

[17] AOAC. Official methods of analysis 15th Edition, Association of Official Analytical Chemists, Arlington, Washington D.C, 1990.

[18] BIPEA., Bureau Interprofessionnel d'Etudes Analytiques: Recueil de méthodes d'analyses des communautés européennes, Gennevilliers, France, 1976.

[19] Wolf, J.P., Manuel d'analyses des corps gras. Azoulay; Paris, France, 1968.

[20] Boakye, A. A., Wireko-Manu, F. D., Oduro, I., Ellis, W.O., Gudjónsdóttir, M., Chronakis, I. S., "Utilizing cocoyam (Xanthosoma sagittifolium) for food and nutrition security: a review", Food Science \& Nutrition, vol. 6, no. 4, pp. 703-713, 2018. 
[21] FAO, Food energy - methods of analysis and conversion factors, Food and Agriculture Org anization of United Nations, Rome, 2003.

[22] Kouassi, J.B., Mas sara, C.C., Sess, D.E., Tiahou, G.G., Monde, A.A., Djohan, F.Y., "Détermination des teneurs en magnés ium, potassium, manganèse et sodium de deuxvariétés de gombo", Journal of Applied Bios ciences, vol. 67, pp.5219-5227, 2013a.

[23] Singleton, V.L., Orthofer, R., Lamuela-Raventos, R.M., "Analysis of total phenols and other oxidant substrates and antioxidands by means of Folin-ciocalteu reagent”, Methods in enzymology, vol. 299, pp. 152-178, 1999.

[24] Pongracz, G., Weiser, H., Matzinger, D., “Tocopherols-antioxydant”, Fat Science Technology, vol. 97, no.3, pp. 90104, 1971.

[25] Nair, B.R., Fahsa, K.S., "Is olation and characterization of mucilage froms ome selected s pecie s of Abelmo schus medik. (Malvaceae) and their application in pharmaceutical suspension preparation", International Journal of Pharmacy and Pharmaceutical Sciences, vol. 5, no 1, pp. 398-402, 2013.

[26] Ewa, C., Agnieszka, G., Adametal, F., "The content of protein and of amino acids in Jerus alem artichoke tubers (Helianthus tuberosus L.) of red variety Rote Zonenkugel”, Acta ScientiarumPolonorum. Technologia Alimentaria, vol. 10, no.4, pp.433-441, 2011.

[27] Sami, R., Lianzhou, J., Yang, L., Ma, Y., Jing, J., "Evaluation of fatty acid and amino acid compositions in okra (Abelmoschus esculentus) grown in different geographical Locations", BioMed Research Internatio nal, vol. 2013, no. 4 pp. 1-6, 2013.

[28] Mensan, J. K., Okoli, R. I., Ohaju-Obodo, J. O., Eifediyi, K., "Phytochemical, nutritional and medicinal properties of some leafy vegetables consumed by Edo People of Nigeria", African Journal of Biotechnology, vol. 7, , no. 14 pp. 2304-2309, 2008.

[29] Ngoc, T.H., Ngoc, Q.N., Tran, V.A., Phung, N.V., "Hypolipidemic effect of extracts fromAbelmoschus esculentus L. (Malvaceae) on Tyloxapol-induced hyperlipidemia in mice", Pharmaceutical Sciences Asia, vol. 35, no. 1-4, p p . 42-46, 2008.

[30] Dawczynski, C., Schubert, R., Jahreis, G., "Amino acids, fatty acids, and dietary fiber in edible seaweed produ cts", Food Chemistry, vol. 103, no. 3, pp. 891-899, 2007.

[31] Olaofe, O., Okiribiti, B.Y., Aremu, M.O., "Chemical evaluation of the nutritive value of smooth Luffa cylindrica seed's kernel”, Electronic Journal of Environmental, A gricultural and Food Chemis try, vol. 7, no.10, pp. 3444-3452, 2008.

[32] Ogungbenle, H.N., Omosola S.M., "The comparative assessment of nutritive values of dry Nigerian okra (Abelmoschus esculentus) fruit and oil", International Journal of Food Science and Nutrition Engineering, vol. 5, no. 1, pp. 8-14, 2015.

[33] Messing, J., Thöle, C., Niehues, M., Shevtsova, A., Glocker, E., Hensel, A., "Antiadhesive properties of Abelmoschus esculentus (okra) immature fruit extract against Helicobacter pylori adhesion”, PLoS One, vol. 9, no. 1, pp. 84836, 2014.

[34] Marinova, D., Ribarova, F., Atanassova, M., "Total phenolics and total flavonoids in bulgarian fruits and vegetables", Journal of the University of Chemical Technology and Metallurgy, vol. 40, no. 3, pp. 255-260, 2005.

[35] Saeed, N., Khan, M.R., Shabbir, M., "Antioxidant activity, total phenolic and total flavonoid contents of whole plant extracts Torilis leptophylla L”, BMC Complementary and Alternative Medicine, vol. 12, no. 1, pp. 221, 2012.

[36] Arkoub-djermoune, L., Boulekbache-makhlouf, L., Zeghichi-hamri, S., Bellili, S., Boukhalfa, F., Madani, K., "Influence of the thermal processing on the physicochemical propreties and the antioxidant activity of a solan aceae vegetable: eggplant”, Journal ofFood Quality, vol. 39, no.3, pp. 181-191, 2016.

[37] Eze, J., Akubor,P., "Effect of drying methods and storage on the physicochemical properties of okra", Jou rnal of Food Processing and Technology, vol. 3, no. 8, pp. 172-177, 2012.

[38] Chuah, A.M., Lee, Y.C., Yamaguchi, T., Takamura, H., Yin, L.J., Matoba, T., "Effect of cooking on the antioxidant properties of coloured peppers", Food Chemis try, Vol. 111, no. 1, pp. 20-28, 2008.

[39] Ibanga, O.I., Okon, D.E., "Minerals and antinutrients in two varieties of African pear(Dacryodes edulis)", Journal of Food Technology, vol. 7, no. 4, pp. 106-110, 2009.

[40] Sen, S., Mukherji, S., "Seas on-dependent mineral accumulation in fruits of okra (Abelmoschus esculentus) and tomato (Lycopersicon esculentum)", Journal of Environmental Biology, vol. 23, no.1, pp. 47-50, 2002.

[41] Elinge, C M., Muhammad, A., Atiku, F A., Itodo, A U., Peni, I J., Sanni, O M., "Proximate, mineral and antinutrient composition of pumpkin (Cucurbitapepo L) seeds extract", International Journal of Plant Research, vol. 2 , no. 5, pp. 146-150, 2012.

[42] Arinathan, V., Mohan, V. R., De Britto, A. J., "Chemical composition of certain tribal pulses in South India", International Journal of Food Sciences and Nutrition. Vol. 54, no.3, pp. 209-217, 2003. 
[43] Kouassi, J.B., Mass ara, C.C., Sess, D.E., Tiahou, G.G., Monde, A.A., Djohan, F.Y., "Détermination des teneurs en fer, en calcium, en cuivre et en zinc de deux variétés de gombo", Bulletin de la Société Royale des Sciences de Liège, vol. 82 pp. 22-32, 2013b.

[44] Ndangui, C.B., Kimbonguila, A., Nzikou, J.M., Matos, L., Pambou-Tobi, N.P.G., Abena, A.A., Silou, T., Sch er, J., Desobry, S., "Nutritive Composition and Properties Phy sico-chemical of gumbo (Abelmoschus es culentus L.) Seed and Oil", Research Journal of Environmental and Earth Sciences, vol. 2, no. 1, pp. 49-54, 2010.

[45] Whitney, E.N., Hamilton, E.M.N., Rolfes, R., "Understanding nutrition”, New York: West Publis hing Co mp an y, 1990. 